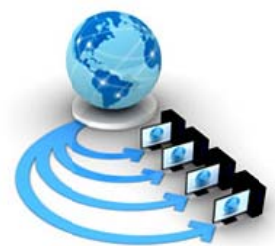

Volume 9, No. 1, January-February 2018

International Journal of Advanced Research in Computer Science

RESEARCH PAPER

Available Online at www.ijarcs.info

\title{
AN APPROACH TO IDENTIFY NOISE IN IMAGES AND APPLY RESTORATION TECHNIQUE TO REMOVE NOISE
}

\begin{abstract}
Suwarna Gothane
Associate Professor,

CSE Dept, CMR Technical Campus, Hyderabad, India, Research Scholar, Sant Gadge Baba Amravati University, India

\author{
Dr. V. M. Thakre \\ Professor, \\ Sant Gadge Baba Amravati University, India
}

Abstract: Increase in road transportation in India demands present research movements to provide safe road. Maintenance of road and traffic control is one of the important issue for country like India. The safety and traffic situations are depend partly on the road conditions, for Indian road. Hence, the preventive measures for the road conditions are significant factor to consider for road authorities. Various researchers focus on automation of road maintenance. We have studied accuracy will depend on the quality of the input images. Input data can easily be improved by using various high definition capture devices which lead towards higher cost factor and low value propositions. Thus, improving the input image quality is the basic need to improve the accuracy for detecting the road conditions. Here, we studied different types of noise and effective way of noise removal using Legendre restoration technique.
\end{abstract}

Keywords: noise, restoration, road, maintenance

\section{I .INTRODUCTION}

The digital images are one of the common sources of data representation and transmission. There is continuous effort carried out to process and present superior images. In image processing facial image is the main research from past 2 decades. Much of the work processed in recognition of facial images for security, capable data management, automations and emotion detection. However the collection of input images strongly depends on capture device. Thus the researchers are making continuous efforts to enhance image quality. The major drawback for recognition of facial images consists of random distortion and blurring due to the noise [1], [4].

\section{LITERATURE SURVEY}

Major sources of the distortion, blurriness are environmental and human errors and quality of capturing device. Blurriness in images cause due to focal length of the capture devices, when not adjusted properly with the sync of distance between the object and the length. Captured object in a time irrelevant scale mapped with the capture speed of the agent to stay away from the blurriness studied by [2].Environmental and human causes problem when object is in advanced order of colour range, background of lower order of colour range. Thus to remove the effect of blurriness of the image, momentary calculation algorithms provides efficient results. Moments are the numeric values used to signify the nature of any functions and recognize the significant properties proposed by [2],[3]. Moment correspond to a normally calculated average value denoted as image descriptor used for reconstruction or other recognition tasks. The most widely used moments algorithms are Hu moment, Zernike moment and Legendre algorithms.

\section{DIFFERENT TYPES OF NOISES}

Noise is random signal and can destroy some information present in images. Distortion in images caused by types of noise such as Gaussian noise, Poisson noise, Speckle noise, Salt and Pepper noise.

\section{A. Salt and Pepper:}

Salt-and-pepper noise occur by difficulty in the image signal present with white and black pixels. Noise reduction technique for salt and pepper noise is median filter [5]or amorphological filter[6] worked with salt noise or pepper noise removal using contraharmonic mean filter[7]. Removal of impulse noise using median median filters causes blurring and results in distorted edges and lacks quality. [8] proposed method based on thresholding of pixels for noise removal by median filter using selective pixels that are not noise themselves. Results obtained were compared with usual median filter and center weighted median (CWM) filter and achieved better results.[9]proposed Cellular Automata computational tools for nature and bioinspired computing for efficient approach of grayscale images. Used 2D Moore neighborhood, proved worthy for removal of high-noise levels.[10] modified Adaptive Threshold Median Filter for salt and pepper noise removal on color images of low and high-density noise levels. Results compared with Peak Signal Noise Ratio values and Mean Square Error method and achieved better results. 


\section{B. Poisson:}

Poisson distribution is due to photon arrival process and uncertainty associated with the measurement of light. Magnitude of poisson noise is signal dependent and main source of noise apart from low-light conditions.

\section{Speckle:}

Speckle is a granular noise exist in active radar, synthetic aperture radar, medical ultrasound and optical coherence tomography images. On synthetic or natural surfaces noise is extremely rough on the scale of the wavelength within the resolution cell. Constructive and destructive interference identified as bright and dark dots in the image and distributed as scatterers[11].Speckle noise in conventional radar results from random fluctuations in the return signal from an object and raise the mean grey level of a local area[12].This noise causes troubles for data understanding[12][13]. It is caused by coherent processing of backscattered signals from multiple distributed targets. Speckle noises are signals from elementary scatterers, the gravity-capillary ripples, and manifests as a pedestal image, beneath the image of the sea wave[14][15].

\section{Gaussian:}

Data acquisition is one of the source of Gaussian noise. Factors leads to Gaussian noise are noise present in sensor of illumination and its temperature, and connected electronic circuit. [16]Gaussian, is additive, independent at pixel, and at signal intensity.[17]Amplifier noise is caused due to image sensor and constant noise level in dark areas.[18] In color cameras where added amplification used in the blue color channel as compared to green or red channel, leads to noise in the blue channel.[19] proved at higher exposures sensor noise is subject by shot noise, not Gaussian and not independent of signal intensity.[20] acquired data from remote sensing satellites and processed with white Gaussian noise of zero mean and constant variance. Noise denoised through Legendre Fenchel Transformation, and compared with results obtained by Euler-Lagrange ROF model and proved highly convergent and a lesser amount of time.

\section{ARCHITECTURE OF PROPOSED SYSTEM}

We have considered images of Indian road network and degrades image with salt and pepper, Gaussian, Poisson and Speckle Noise. Images are restored with Legendre Moment. We have noticed for digital images Legendre moment outperforms with good results.(Fig 1)

\section{IMPLEMENTATION}

For implementation of work we used images captured from the Indian road of Maharashtra region collected from public work department.

Input images degraded with estimated angle, length with noise such as salt and pepper, Gaussian, Poisson, Speckle and restored images SNR calculated consider ing 10 images. We have observed signal to noise ratio reduced and better results derived as compared to the noisy images SNR.

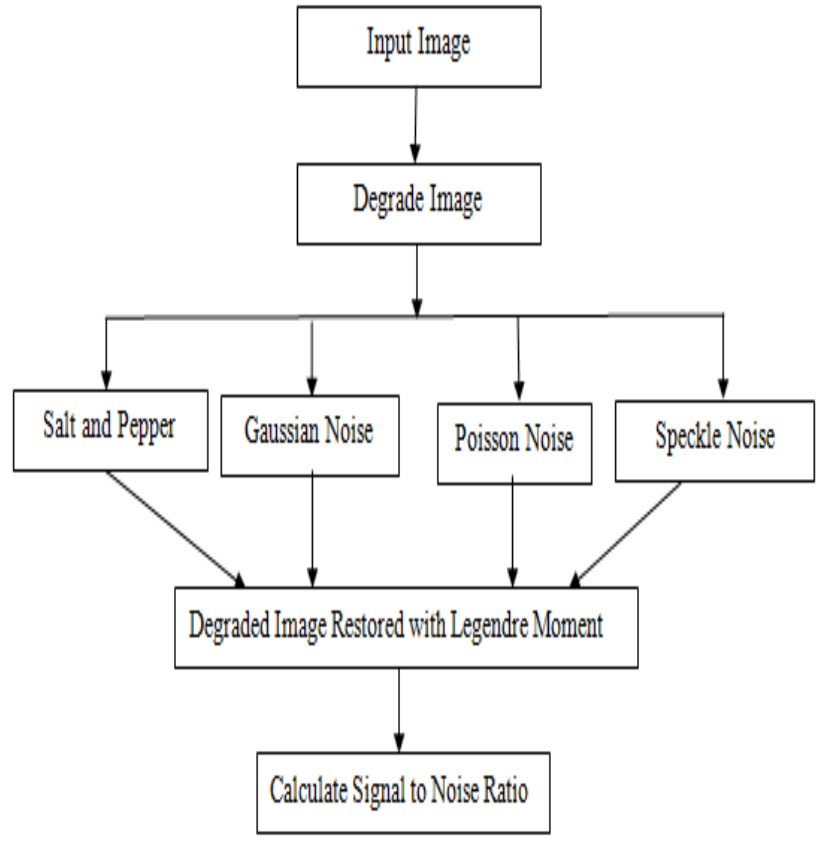

Fig1: Architecture of proposed system
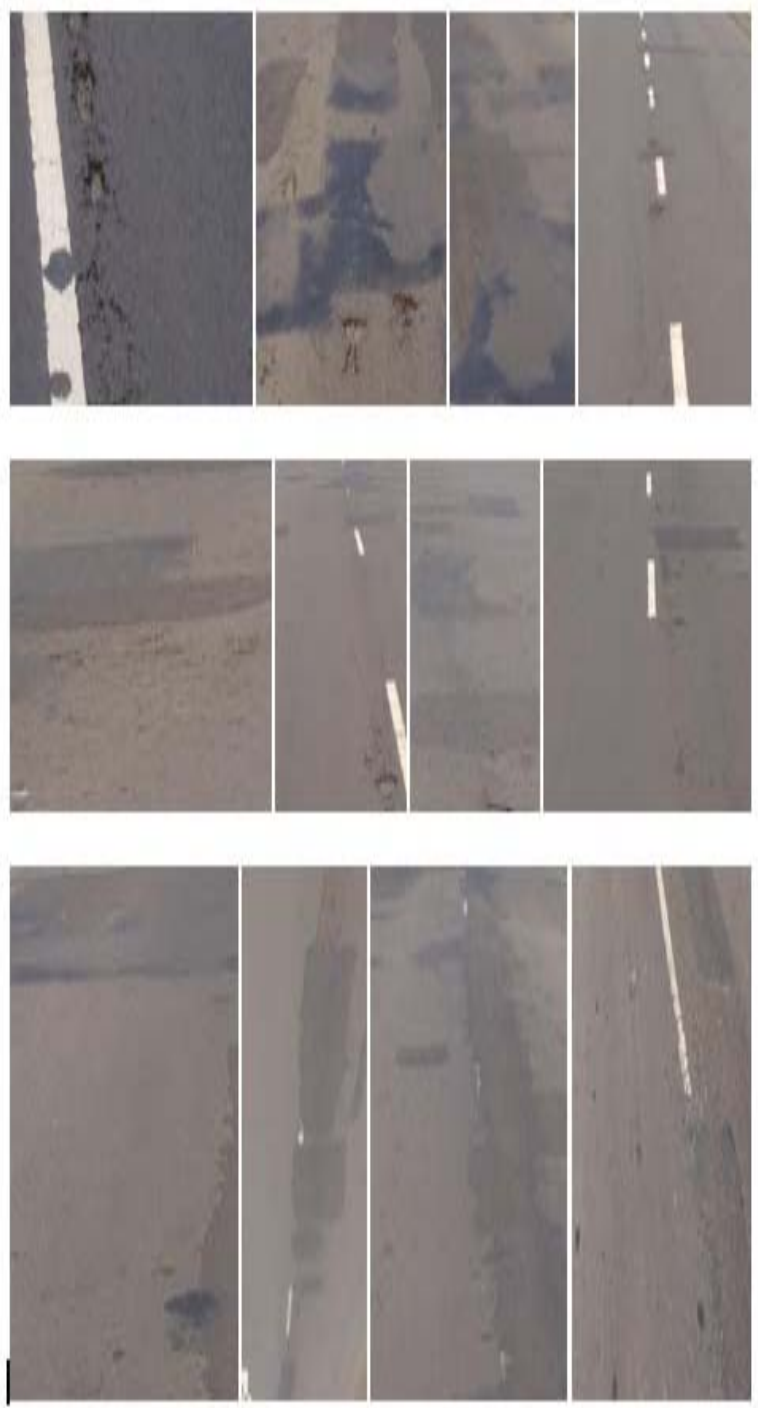

Fig2: Input Images 
Table1: Results of SNR

\begin{tabular}{|c|c|c|c|c|c|}
\hline $\begin{array}{l}\text { Sr. } \\
\text { No }\end{array}$ & $\begin{array}{l}\text { Noise } \\
\text { Type }\end{array}$ & Angle & $\begin{array}{l}\text { Le } \\
\text { ng } \\
\text { th }\end{array}$ & $\begin{array}{l}\text { Restoration } \\
\text { Technique }\end{array}$ & $\begin{array}{l}\mathrm{S} \\
\mathrm{N} \\
\mathrm{R}\end{array}$ \\
\hline \multirow[t]{4}{*}{$\operatorname{Im} 1$} & $\begin{array}{l}\text { Salt and } \\
\text { Pepper }\end{array}$ & 180 & 53 & $\begin{array}{l}\text { Legendre } \\
\text { Moment }\end{array}$ & 0.0012 \\
\hline & Gaussian & 178 & 13 & $\begin{array}{l}\text { Legendre } \\
\text { Moment }\end{array}$ & 0.0012 \\
\hline & Poisson & 180 & 75 & $\begin{array}{l}\text { Legendre } \\
\text { Moment }\end{array}$ & 0.0012 \\
\hline & Speckle & 45 & 3 & $\begin{array}{l}\text { Legendre } \\
\text { Moment }\end{array}$ & 0.0012 \\
\hline \multirow[t]{4}{*}{$\operatorname{Im} 2$} & $\begin{array}{l}\text { Salt and } \\
\text { Pepper }\end{array}$ & 180 & 42 & $\begin{array}{l}\text { Legendre } \\
\text { Moment }\end{array}$ & 0.0013 \\
\hline & Gaussian & 179 & 3 & $\begin{array}{l}\text { Legendre } \\
\text { Moment }\end{array}$ & 0.0013 \\
\hline & Poisson & 180 & 40 & $\begin{array}{l}\text { Legendre } \\
\text { Moment }\end{array}$ & 0.0013 \\
\hline & Speckle & 45 & 34 & $\begin{array}{l}\text { Legendre } \\
\text { Moment }\end{array}$ & 0.0013 \\
\hline \multirow[t]{4}{*}{$\operatorname{Im} 3$} & $\begin{array}{l}\text { Salt and } \\
\text { Pepper }\end{array}$ & 180 & 43 & $\begin{array}{l}\text { Legendre } \\
\text { Moment }\end{array}$ & 0.0013 \\
\hline & Gaussian & 179 & 3 & $\begin{array}{l}\text { Legendre } \\
\text { Moment }\end{array}$ & 0.0013 \\
\hline & Poisson & 90 & 17 & $\begin{array}{l}\text { Legendre } \\
\text { Moment }\end{array}$ & 0.0013 \\
\hline & Speckle & 179 & 3 & $\begin{array}{l}\text { Legendre } \\
\text { Moment }\end{array}$ & 0.0013 \\
\hline \multirow[t]{4}{*}{$\operatorname{Im} 4$} & $\begin{array}{l}\text { Salt and } \\
\text { Pepper }\end{array}$ & 180 & 37 & $\begin{array}{l}\text { Legendre } \\
\text { Moment }\end{array}$ & 0.0041 \\
\hline & Gaussian & 154 & 3 & $\begin{array}{l}\text { Legendre } \\
\text { Moment }\end{array}$ & 0.0041 \\
\hline & Poisson & 180 & 19 & $\begin{array}{l}\text { Legendre } \\
\text { Moment }\end{array}$ & 0.0041 \\
\hline & Speckle & 180 & 19 & $\begin{array}{l}\text { Legendre } \\
\text { Moment }\end{array}$ & 0.0041 \\
\hline \multirow[t]{4}{*}{$\operatorname{Im} 5$} & $\begin{array}{l}\text { Salt and } \\
\text { Pepper }\end{array}$ & 180 & 34 & $\begin{array}{l}\text { Legendre } \\
\text { Moment }\end{array}$ & 0.0019 \\
\hline & Gaussian & 116 & 28 & $\begin{array}{l}\text { Legendre } \\
\text { Moment }\end{array}$ & 0.0019 \\
\hline & Poisson & 180 & 21 & $\begin{array}{l}\text { Legendre } \\
\text { Moment }\end{array}$ & 0.0019 \\
\hline & Speckle & 135 & 3 & $\begin{array}{l}\text { Legendre } \\
\text { Moment }\end{array}$ & 0.0019 \\
\hline \multirow[t]{4}{*}{$\operatorname{Im} 6$} & $\begin{array}{l}\text { Salt and } \\
\text { Pepper }\end{array}$ & 180 & 57 & $\begin{array}{l}\text { Legendre } \\
\text { Moment }\end{array}$ & 0.0014 \\
\hline & Gaussian & 178 & 17 & $\begin{array}{l}\text { Legendre } \\
\text { Moment }\end{array}$ & 0.0014 \\
\hline & Poisson & 180 & 80 & $\begin{array}{l}\text { Legendre } \\
\text { Moment }\end{array}$ & 0.0014 \\
\hline & Speckle & 178 & 3 & $\begin{array}{l}\text { Legendre } \\
\text { Moment }\end{array}$ & 0.0014 \\
\hline \multirow[t]{4}{*}{$\operatorname{Im} 7$} & $\begin{array}{l}\text { Salt and } \\
\text { Pepper }\end{array}$ & 90 & 11 & $\begin{array}{l}\text { Legendre } \\
\text { Moment }\end{array}$ & 0.0018 \\
\hline & Gaussian & 32 & 27 & $\begin{array}{l}\text { Legendre } \\
\text { Moment }\end{array}$ & 0.0018 \\
\hline & Poisson & 180 & 20 & $\begin{array}{l}\text { Legendre } \\
\text { Moment }\end{array}$ & 0.0018 \\
\hline & Speckle & 65 & 3 & $\begin{array}{l}\text { Legendre } \\
\text { Moment }\end{array}$ & 0.0018 \\
\hline $\operatorname{Im} 8$ & $\begin{array}{l}\text { Salt and } \\
\text { Pepper }\end{array}$ & 180 & 21 & $\begin{array}{l}\text { Legendre } \\
\text { Moment }\end{array}$ & 0.0023 \\
\hline
\end{tabular}

\begin{tabular}{|c|c|c|c|c|c|}
\hline & Gaussian & 179 & 3 & $\begin{array}{l}\text { Legendre } \\
\text { Moment }\end{array}$ & 0.0023 \\
\hline & Poisson & 180 & 19 & $\begin{array}{l}\text { Legendre } \\
\text { Moment }\end{array}$ & 0.0023 \\
\hline & Speckle & 153 & 3 & $\begin{array}{l}\text { Legendre } \\
\text { Moment }\end{array}$ & 0.0023 \\
\hline \multirow[t]{4}{*}{$\operatorname{Im} 9$} & $\begin{array}{l}\text { Salt and } \\
\text { Pepper }\end{array}$ & 180 & 21 & $\begin{array}{l}\text { Legendre } \\
\text { Moment }\end{array}$ & 0.0011 \\
\hline & Gaussian & 179 & 38 & $\begin{array}{l}\text { Legendre } \\
\text { Moment }\end{array}$ & 0.0011 \\
\hline & Poisson & 1 & 28 & $\begin{array}{l}\text { Legendre } \\
\text { Moment }\end{array}$ & 0.0011 \\
\hline & Speckle & 179 & 3 & $\begin{array}{l}\text { Legendre } \\
\text { Moment }\end{array}$ & 0.0011 \\
\hline \multirow[t]{4}{*}{$\operatorname{Im} 10$} & $\begin{array}{l}\text { Salt and } \\
\text { Pepper }\end{array}$ & 180 & 38 & $\begin{array}{l}\text { Legendre } \\
\text { Moment }\end{array}$ & 0.0016 \\
\hline & Gaussian & 180 & 51 & $\begin{array}{l}\text { Legendre } \\
\text { Moment }\end{array}$ & 0.0016 \\
\hline & Poisson & 180 & 25 & $\begin{array}{l}\text { Legendre } \\
\text { Moment }\end{array}$ & 0.0016 \\
\hline & Speckle & 180 & 37 & $\begin{array}{l}\text { Legendre } \\
\text { Moment }\end{array}$ & 0.0016 \\
\hline
\end{tabular}

\section{CONCLUSION AND FUTURE WORK}

In the study of road network safety, maintenance of the roads so far follows manual approach and needs to be improved to fast up process with automation. In the study we noticed one of the significant improvements on automatic detection of the road condition depends on the image quality captured. So for further analysis input image should be free of noise and blur factors. Hence, this work demonstrates an automatic approach to detect and restore noise within images. The result obtained from this work is noteworthy and provides better analysis of road conditions and processing.

\section{REFERENCES}

[1] B. Chen , H. Shu , H. Zhang, G. Coatrieux , L. Luo and J. L. Coatrieux "Combined invariants to similarity transformation and to blur using orthogonal Zernike moments", IEEE Trans. Image Process., vol. 20, no. 2, pp.345 -360, 2011.

[2] H. Zhang, H. Shu, G.-N. Han, G. Coatrieux , L. Luo and J. L. Coatrieux, "Blurred image recognition by Legendre moment invariants", IEEE Trans. Image Process, vol. 19, no. 3, pp.596 -611, 2010.

[3] H. Zhu, M. Liu, H. Ji and Y. Li, "Combined invariants to blur and rotation using Zernike moment descriptors", Pattern Anal. Appl, vol. 3, no. 13, pp.309 -319, 2010.

[4] X. Dai, H. Zhang, H. Shu and L. Luo "Image recognition by combined invariants of Legendre moment", Proc. IEEE ICIA, pp.1793 -1798, 2010 .

[5] Jayaraman, “Digital Image Processing”, Tata McGraw Hill Education, p. 272. ISBN 9781259081439, 2009.

[6] Rosin Paul, Collomosse John, "Image and Video-Based Artistic Stylisation”, Springer. p. 92. ISBN 9781447145196, 2012.

[7] Marques, Oge, "Practical Image and Video Processing Using MATLAB”, Wiley. pp. 275276. ISBN 9781118093481, 2011.

[8] S. Deivalakshmi, S. Sarath, P. Palanisamy, "Detection and removal of Salt and Pepper noise in images by improved 
median filter”, Published in: Recent Advances in Intelligent Computational Systems (RAICS), IEEE, 03 November 2011.

[9] Dimitrios Tourtounis, Nikolaos Mitianoudis, Georgios Ch. Sirakoulisy, "Salt and Pepper Noise Filtering Using Cellular Automata”, Democritus University Of Thrace Department Of Electrical And Computer Engineering, University Campus Duth,Xanthi $671 \quad 00, \quad$ Greece,Arxiv:1708.05019v1 [Cs.CV] ,16 Aug 2017.

[10] Pranay Yadav, "Color image noise removal by modified adaptive threshold median filter for RVIN”, Published in: Electronic Design, Computer Networks \& Automated Verification (EDCAV), International Conference ,29-30 Jan. 2015,Proc. IEEE Xplore. 16 March 2015.

[11] M. Forouzanfar, H. Abrishami-Moghaddam, "Ultrasound Speckle Reduction in the Complex Wavelet Domain, in Principles of Waveform Diversity and Design”, M. Wicks, E. Mokole, S. Blunt, R. Schneible, and V. Amuso (eds.), SciTech Publishing, Section B - Part V: Remote Sensing, pp. 558-77,2010.

[12] Brandt Tso, Paul Mather, "Classification Methods for Remotely Sensed Data”, 2nd ed, CRCPress. pp. 3738. ISBN 9781420090727, 2009.

[13] Giorgio Franceschetti, Riccardo Lanari , " Synthetic aperture radar processing”, Electronic engineering systems series. CRC Press. pp. 145 et seq. ISBN 9780849378997, 1999.

[14] Mikhail B.Kanevsky, "Radar imaging of the oceanwaves”, Elsevier.p. 138. ISBN 9780444532091, 2008.

[15] Alexander Ya Pasmurov \& JuliusS. Zinoviev, "Radar imaging and holography”, IEEE radar, sonar and navigation series. 19.IET. p. 175. ISBN 9780863415029, 2005.

[16] Philippe Cattin, "Image Restoration: Introduction to Signal and Image Processing". MIAC, University of Basel, 11 October 2013.[17] Jun Ohta, "Smart CMOS Image Sensors and Applications”, CRC Press. ISBN 0-8493-3681-3, 2008.

[18] Junichi Nakamur, "Image Sensors and Signal Processing for Digital Still Cameras”, CRC Press. ISBN 0-8493-3545-0, 2005.

[19] Lindsay Mac Donald, "Digital Heritage”, ButterworthHeinemann. ISBN 0-7506-6183-6,2006.

[20] Rashmi G. , Sowmya V., Soman K.P.,“A novel approach for denoising coloured remote sensing image using Legendre Fenchel Transformation”, InternationalConference on Recent Trends in Information Technology ,April2014, Proc. IEEE 29 Dec2014.

\section{ABOUT THE AUTHORS}

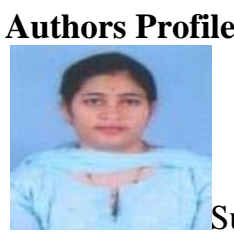
Associate Professor in CMR Technical campus, Hyderabad, Telangana, India. She is pursuing Ph.D. from Sant Gadge Baba Amravati University. She received her M.E (CSE) degree from P.R.M.I.T \& R, Amravati in the year 2012. She received B.E. (CSE) degree from H.V.P.M C.O.E \& T, in the year 2006. Her areas of interests are Data Mining, Image Processing, Machine learning etc.

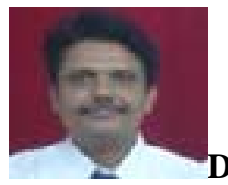

Dr. Milindkumar Sarode currently working as HOD. Government Polytechnic, Yavatmal, India. He has completed his $\mathrm{Ph}$. D in Computer Science and Engg. His research area includes Digital Image processing and Algorithms, Distributed System and Data Analysis.

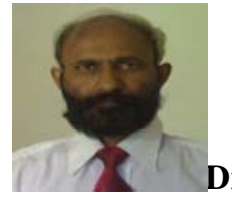

Dr. Vilas M. Thakare currently working as Professor and Head in Computer Science, Faculty of Engineering \& Technology, Post Graduate Department of Computer Science, SGBAU. He has completed his Ph.D. in Computer Science. His research interest includes Networking, Mobile Computing, Cyber Security, AI and Robotics. 